\title{
DESIGNING STOP MOTION VIDEO USING LEARNING STYLE APPROACH TO TEACH VOCABULARY AT 4TH GRADE SD MUHAMMADIYAH PURWODININGRATAN II IN THE ACADEMIC YEAR 2015/2016
}

\author{
M. Luthfi Imama ${ }^{1}$, Rahmi Munfangati ${ }^{2}$ \\ ${ }^{1}$ Universitas Ahmad Dahlan, Indonesia \\ 1'Imamaluthfi@ymail.com \\ ${ }^{2}$ Universitas Ahmad Dahlan, Indonesia \\ ${ }^{2}$ Rahmi@pbi.uad.ac.id
}

\begin{abstract}
This research was proposed to design Stop Motion video using learning style approach as a media to teach vocabulary for 4th grade students of SD Muhammadiyah Purwodiningratan II in the academic year 2015/2016.

ADDIE (Analyze, Designing, Developing, Implementation, and Evaluating) was used by the researcher as a research methodology. The data for needs and learning style analysis was collected by giving questionnaire, doing an interviews and doing observation in the classroom. In order to develop the Stop Motion video, the prototype of the product was evaluated by the expert. Then, the video was implemented on the learning process to know its feasibility. In order to measure the effectiveness of the Stop Motion video, pre-test and post-test were given to class 4.A.1 as an experiment class and class 4.A.2 as a control class. The data of the pre-test and post-test were calculated by using SPSS 16.00. After the implementation, the researcher conducted an evaluation by analyzing the response of the student to the media. The result of the research suggested that stop motion video suitable to teach 4 grade elementary students of SD Muhammadiyah Purwodiningratan II.
\end{abstract}

Keywords: stop motion video, learning style, vocabulary teaching, elementary students

\section{INTRODUCTION}

English is one of the education subjects in Indonesia. English was introduced as school subject in 1914 in the Dutch Government School (Lauder,2008:9) There are so many factors to achieve a good English capability. The most important thing is to find the key to achieve that. Mastering vocabulary can become a key to learn English better. Vocabulary is a supportive aspect to teach four language skills. Despite only a support aspect, vocabulary becomes the important part in teaching and learning activity. As accordance to River in Nunan (1991:117) stated that without extensive vocabulary, we will be unable to use the structures and function we may have learned for comprehensive communication. It resembles that excluding a richness of vocabulary, the teaching and learning process cannot be optimal.

The vocabulary mastery in Indonesia still can be categorized as a less. Nurweni on Bambang and Widiati (2007) explained that Indonesian students only acquire 7 words per weeks, it is only a half rather than the theory which said student must achieve 14 words per weeks. By the statement from Nurweni, the vocabulary mastery in Indonesia is still

less. Media development and students' treatment are the main factor why the vocabulary learning does not develop properly. That is why the problem which teacher will face is also different from teaching the adult. Children are easily getting bored when studying. They can be very active and interest with something new. If the teacher does not pay attention to it, it will be hard to teach student. 
The researcher tries to find a solution from the problem mentioned by designing Stop-Motion Video to teach vocabulary to the student with learning style approach. Learning style will make teacher easier to give treatment toward the student. Stop motion video is a video made by a sequence of photos or picture which is played in certain speed to produce an animation. It became popular in the late of 2012 by the TV animation series "Shaun, the sheep". This video can be applied in teaching English.

Learning English is much way interesting to children because it is colorful and interesting, the children will get an experience as they are watching cartoon movie on TV. The aims of this research is to design Stop Motion Video for teaching and learning vocabulary based on learning style approach, to find the students' response to the Stop-motion Video based on learning style, and to describe the effectiveness of using Stop Motion video with learning style approach to teach vocabulary for 4th grade elementary school students.

\section{LITERATURE REVIEW}

2.1 Vocabulary

2.1.1 Definition of Vocabulary

Bussman (1998:1268) said that "vocabulary is a complete list of all the word in a language at a specific point in a time". Meanwhile Based on Nunan (1999: 103) explains that "Vocabulary supposed as a primarily important element on language development". Crystal $(2008,512)$ make a distinction on vocabulary, The first is active vocabulary which means a lexical item people used and passive vocabulary is a vocabulary that people known but they rarely used them.

\subsubsection{Vocabulary Mastery}

Vocabulary mastery means total amount of world which we can mastered and use it in the communication context. Mastery according to Oxford Learner Dictionary 4 edition (2008) is a great skill or knowledge in particular thing. Vocabulary mastery maybe different from native to a second or Foreign Language user. Nation (2001) stated that minimum amount of vocabulary mastery by the foreign language user is 2000 words on High frequency words.

2.2 English Language Teaching

\subsubsection{Definition of English Language Teaching}

Brown (1987:7) defines "teaching as guiding and facilitating learning which enable the learner to learn, setting the education for learning". English Language Teaching is a branch of Language Teaching in the world. English has a great influence in the world lately because it becomes a global language right now. Harmer (2009:11) said that People learn English because it became a target-community language. They believe it would be useful in their international communication and travel.

2.3 English Language Teaching Methods

English Language teaching has many different methodologies on its way to teach. Every kind of methods brings its own benefit or the weakness. Harmer (2009) and Patel (2007) describe the method of English language teaching into 6 common methods but the writer comes to only one of them, it is Grammar Translation Method

Grammar Translation Methods is the oldest English Language Teaching. Usually called as Classical method, Grammar Translation Methods is very famous in 1840 to the 1940s. Grammar Translation Methods pay much attention on 
Language syntax and part of speech. The benefit of Grammar translation methods is great to improve vocabulary mastery and develop the art of translation. However, Grammar Translation Method does not bring an opportunity for learner to activate the language usage and competence.

\subsection{Language Learner}

Harmer (2009) also decided the learner differences on their studies. Harmer have 4 types of the learner based on their ages. But the researcher will focus on Children. Children are a phase of human when they are on 0-9 years old. Children hardly focus on the learning. However, they also learn everything around them in one time. They are difficult to think Abstract and pay much attention on what they hear, see, and touch. Although they hard focus and concentrate, Children response very well to the learning. It is when the material is about their daily life. or experiences. The Crucial characteristic of the children is they have a great ability to become a new-language user. Children phase is a golden age to acquire a language.

\subsection{Technique of Teaching Vocabulary}

Loci technique is the one used by the researcher. These are form of mnemonic in which a list of words to be learned are associated with familiar visual image such as a room or well-known tourist spot. Each word is associated in some way with one of the items in the visual image, and the image is used to assist in the recall of the words.

2.6 Teaching English to Young Learner

\subsubsection{Definition of TEYL}

According to Harmer (2009:14), "students are generally described as young learners between the ages of about 5 to 9 , and very young learners are usually between 2 and 5." It means that students in Indonesian elementary school can be categorized as young learners. This phase is commonly represented in the third fourth and fifth grades. However, the researcher will only focus on the students at fourth grade.

\subsubsection{Young Learner Characteristic}

Harmer says that, "they take in information from all sides, learning from everything around them rather than only focusing on the precise 11 topics they are being taught. Their understanding comes not just from explanation, but also from what they see and hear and, crucially, have a chance to touch and interact with" ("The Practice of English Language Teaching" 82). Harmer also states that, "unless activities are extremely engaging, they can get easily bored, losing interest after ten minutes or so" ("The Practice of English Language Teaching" 82). Scott and Ytreberg (1995: 3) support these ideas by saying "Young children love to play, and learn best when they are enjoying themselves. But they also take themselves seriously and like to think that what they are doing is reale work".

The young learners' description based on the theories above are nearly similar. Then, the researcher can highlight some characteristics of young learners. First, they do not only learn something in a classroom. They learn everywhere, every time and from everything around them. Second, they need attractive learning activities to make them become more exciting and active physically. The last, they like fun and enjoyable learning activities so they can get the material taught well. 
2.7 Media

2.7.1 Definition of Teaching Media

Gagne in Sudjana (2011:7) explained "Teachingee media is every component in learning environment which helps the learner to learn. Teaching media comes from two roots, teaching and media". According to Setyosari and Sulton (2003:7) "Teaching is an effort conducted by the teacher to help the student to study easily". Media, according to Association of Educational Communication Technology (AECT) in Asyhar (2012:4) is everything used to send information.

2.7.2 Purpose of Teaching Media

There are many reasons why teacher uses media in teaching the Student. They are to ease students' understanding about the materials and exploring more about it.

2.7.3 Types of Teaching Media

The researcher will focus on the use of audio-Visual Media According to Burton on Farooq (2014) Audio-visual media is a sensory objective and image which stimulate and emphasis on learning process. Audio-visual method can show picture (visual) and sound (audio) in the same time when transferring the message or information. Audio-visual media is classified into two types, there are: pure audio-visual media in which the resource of picture and sound come from one source such as cassette video, and impure audio-visual media in which the picture and the sound does not come from one source. Edgar Dale on Gogoi (2014) gives a statement that "audio visual materials supply concrete basis for conceptual thinking, they give rise to meaningful concepts enriched by meaningful association, hence they offer the best antidote for the disease of verbalism".

2.8 Stop Motion Video

2.8.1 Definition of Stop Motion Video

Stop motion video is a kind of animation video. Video is a moving images which are seen in a recording or broadcast (MerriamWebster ${ }^{\text {ee }}$ s online dictionary, n.d.) and animation is the process of recording and playing back a sequence of stills to achieve the illusion of continues motion (Fernandez,2002). Kim (2006:3) defines stop video as animation video which made by interrupting frame after frame, with the animator making changes of puppets in between frames. Thus, stop motion video is an animated video which is produced by disturbing the object to get animation effect.

2.8.2 Type of Stop Motion Video

The motion video focused in this research is Cut-out animation. It is a technique of producing animations using flat characters, props and background cut out from various material such as cardboard, stiff photograph.

\section{METHODS}

3.1 Types of Research

This research could be classified as Research and Development. Research and Development is a research method which is used to produce a new product. The purpose of this research is to produce a certain product to fulfill the learners' need in learning English by designing a media. It is a quantitative data, thus the result should be in concrete form or numeric proves.

3.2 Research Subject, Object and Data 
The research subject is the students at 4th grade of Muhammadiyah Purwodingnratan II elementary school in the academic years 2015/2016. The research object of this study is designed media using stop motion video in mastering the vocabulary. Data is based on the research object and will be taken from research subject. The results of observation, interview, questionnaire and the test to the subject data.

3.3 Method and Technique for Collecting Data

As the researcher uses the quantitative research then the technique to collect data should come directly to the subject in the field. The researcher conducted an observation. After that interview is performed which then followed by questionnaire.

\subsection{Method and Technique for Analyzing Data}

In this study the researcher use ADDIE technique to analyze the Data since the writer starts by analyzing then designing the media, continued by developing the media, followed by implementing the media and the last doing an evaluation.

\section{FINDINGS AND DISCUSSION}

4.1 The Need Analysis

Table 1. Need Analysis Result

\begin{tabular}{|c|c|c|c|}
\hline QUESTION & YES & NO & DON'T KNOW \\
\hline Do you love English subject? & $85 \%$ & $3 \%$ & $12 \%$ \\
\hline Do you ever learn English before elementary school? & $49 \%$ & $33 \%$ & $18 \%$ \\
\hline $\begin{array}{l}\text { Do you take an English supplementary course outside } \\
\text { school? }\end{array}$ & $12 \%$ & $82 \%$ & $6 \%$ \\
\hline Does your teacher teach a new vocabulary everyday? & $66 \%$ & $12 \%$ & $22 \%$ \\
\hline Do you find any difficulty in learning English vocabulary? & $30 \%$ & $50 \%$ & $18 \%$ \\
\hline Is your English score below 70? & $24 \%$ & $72 \%$ & $3 \%$ \\
\hline Do you understand with your teacher's explanation? & $76 \%$ & $9 \%$ & $15 \%$ \\
\hline Does your teacher always use a game in your class? & $21 \%$ & $64 \%$ & $15 \%$ \\
\hline $\begin{array}{l}\text { Does you teacher always play a video or film during } \\
\text { teaching English? }\end{array}$ & $3 \%$ & $88 \%$ & $9 \%$ \\
\hline $\begin{array}{l}\text { Does your teacher always play a music during teaching in } \\
\text { class? }\end{array}$ & $3 \%$ & $92 \%$ & $6 \%$ \\
\hline $\begin{array}{l}\text { Do you like watching video or film when learning } \\
\text { English? }\end{array}$ & $67 \%$ & $27 \%$ & $6 \%$ \\
\hline $\begin{array}{l}\text { Do you like watching a cartoon film, such as sound the } \\
\text { sheep when learning English? }\end{array}$ & $58 \%$ & $36 \%$ & $6 \%$ \\
\hline
\end{tabular}

Based on the whole data above, the students actually feel interested with the English. They also have a good understanding and spirit to learning English. Nevertheless, their teacher rarely uses an innovative media on teaching English. Their curiosity about a new media had increased when the researcher proposed a Stop Motion Video (it is illustrated with "Shaun the sheep" as it has a similarity).

4.2 Interview Analysis

The interview was conducted on Tuesday, $26^{\text {th }}$ April 2016. At 11.00 a.m in SD Muhammadiyah Purwodiningratan II Yogyakarta. The interviewee was the English teacher of class 4, mrs. Tri Hapsari Nugraheni, S.Pd. The data such as students ability, learning methodology and the media in the learning activity.

4.3 Students Problems and ability in learning vocabulary

Students had a great motivation in learning English. They were also very enthusiastic and interested in learning English. Sometimes students knew several new vocab before the teacher explained it in the classroom. Students skill could be 
categorized as balance in 4th grade. There were no superior students nor the inferior. However, the main problem on the class 4 is less concentration and focus. It gave an advanced problem such as a score is below the standard and they do not understand the material. The cause of this problem was a lack of media usage which makes them less interest. Their teacher rarely used a variation in learning media while teaching, then the students started to play and make a noise as a way to release their boredom. From the teacher also, the researcher got they still had a little bit difficulty on Daily activity and times material.

4.4 The media used in learning activity

The teacher rarely used a media while teaching. The teacher only explained and wrote in the board. She did this in order to maximize the time, because the time allocation is very limited the existence of media makes the students got more motivated and interested

4.4.1 The methods used in learning activity

PPP (Presentation, Practice, and Production) is the common method used in

English class on SD Muhammadiyah Purwodiningratan II.PPP was used because it was very effective on developing students' ability in vocabulary and language feature

4.4.2 Learning style approach in learning activity

The teacher did not pay attention much on learning style. She was balancing the teaching method on the classroom and did not focus on certain learning style.

4.4.3 The importance of using stop motion video in learning activity

The use of media was very important on learning process. The teacher also gave a suggestion that the media must be interesting and simple, thus it brought benefits for both students and teacher. Stop Motion would be a new media for teaching English. As it is simple and could increase students' interest and understanding.

4.5 The Result of Learning Style

Table 2. Learning Style Test Result

\begin{tabular}{|c|l|c|c|}
\hline No. & \multicolumn{1}{|c|}{ Category } & Frequency & Percentage (\%) \\
\hline 1 & Students with Auditory learning style preference & 9 & $27 \%$ \\
\hline 2 & Students with Visual learning style preference & 10 & $30 \%$ \\
\hline 3 & Students with Kinesthetic learning style preference & 3 & $9 \%$ \\
\hline 4 & Students with audio-kinesthetic learning style Preference & 3 & $9 \%$ \\
\hline 5 & Students with Audio-visual learning style preference & 4 & $12 \%$ \\
\hline 6 & Students with Visual-kinesthetic preference & 3 & $9 \%$ \\
\hline 7 & Students with Audio-visual-kinesthetic preference & 1 & $3 \%$ \\
\hline & Total & 33 & $99 \%$ \\
\hline
\end{tabular}

Based on the data above, the high percentage of visual and auditory students would support the development of the media. In the other hand, the kinesthetic students would also be supported since the media included an activity designing for kinesthetic students.

4.6 Designing Stop Motion Video

The media was designed based on the result of the need analysis and the learning style analysis by the researcher. The media was designed into a Stop Motion Animation video containing 14 scenes. Each scene showed a kind of vocabulary and the illustration to use that. The production stages were divided into three, a pre-production, production, and post production. 


\subsubsection{Pre-production stage}

There were two kinds of activities in the pre-production stages. The first is designing the script or the storyboard and the second is preparing the material

a. Designing the script

The researcher designed the video into 14 scenes containing a vocabulary on each scene. The vocabularies were set for a daily activity in one day.

b. Preparing the material

The writer chooses to make Stop Motion video with paper-cut technique, the animation material, Manila papers, Asturo papers, White large paper Shooting materials are Scissors, Glue, Needle, Pencil, marker, Eraser, Camera (Nikon D5200), Portable lamp (LED), Tripod.

\subsubsection{Production Stage}

The production stage was started with making the character and the background items. The character and the background was made by cutting and sticking the paper. After the character and the background made, the next steps is placing it in the large white paper.

The picture was taken after the character and the background set. With the help of LED lamp to enlighten the sets, the picture was ready to be taken. The researcher only used a medium category on making the video. It contained 30 pictures for each scene.

4.6.3 Post- Production Stage

It is clearly explained in the figure below

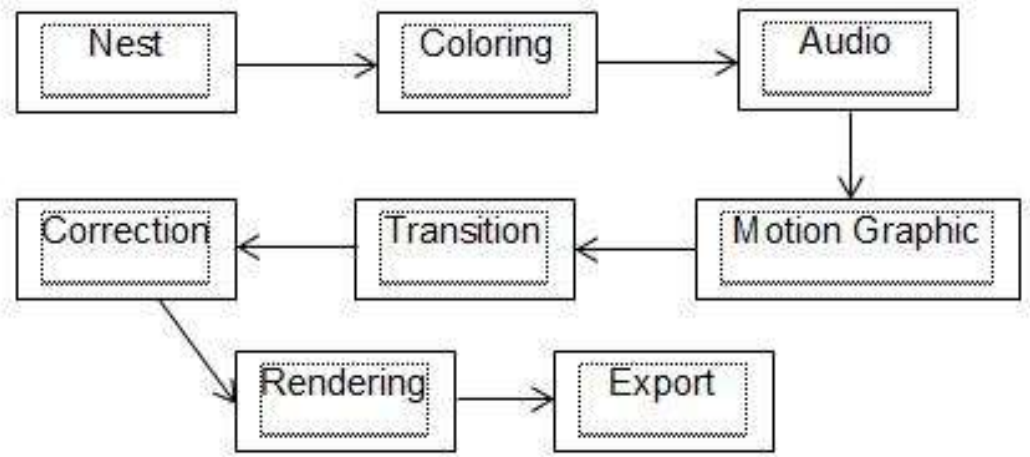

4.7 Development of Stop Motion Video

The development processed was done in two steps. The first is adding the review stage and doing an experiment.

4.8 The Implementation of Stop Motion Video

4.8.1 Pre-test. The test was divided into three parts, the first was jumble words, the second was completing the letter and the third was multiple choices. The pre test was given to class $4 \mathrm{~A} 1$ as the experiment meanwhile $4 \mathrm{~A} 2$ as the controller.

4.8.2 Implementation. At this process, the first thing researcher do was introducing the Stop Motion Video. Then, the researcher taught English vocabulary using Stop Motion video.

4.8.3 Post-test. After the implementation, the researcher conducted the test once again to know the difference. 
4.9 The Result of Implementation

Table 3. The Result of Normality Test

\begin{tabular}{|ll|r|}
\hline 5 & & Unstandardized \\
N & & Residual \\
Normal Parameters & Mean & 29 \\
& Std. Deviation & .0000000 \\
Most Extreme & Absolute & 2.10684854 \\
Differences & Positive & .117 \\
& Negative & .097 \\
Kolmogorov- & & -.117 \\
Smirnov Z & & .630 \\
Asymp. Sig. (2- & & .823 \\
tailed) & & \\
a. Test distribution is Normal. & & \\
\hline
\end{tabular}

Table 4. The result of T-test One-Sample Test

\begin{tabular}{|c|c|c|c|c|c|}
\hline \multicolumn{6}{|c|}{ Test Value $=0$} \\
\hline \multirow[b]{3}{*}{$\mathrm{T}$} & \multirow[b]{3}{*}{ Df } & \multirow[b]{3}{*}{ Sig. (2-tailed) } & \multirow[b]{3}{*}{ Mean Difference } & \multicolumn{2}{|c|}{ 95\% Confidence Interval of the } \\
\hline & & & & \multicolumn{2}{|c|}{ Difference } \\
\hline & & & & Lower & Upper \\
\hline 18.216 & 28 & .000 & 7.179 & 6.37 & 7.99 \\
\hline 30.022 & 28 & .000 & 8.607 & 8.02 & 9.19 \\
\hline
\end{tabular}

Pre-test and the post-test from both classes can be categorized as normal distribution test (above 0,05). Then, based on the result of one sample T-test, there were differences between post-test on class 4.A.1 and class 4.A.2. The post test on the class 4.A.2 was 7.1 and the post-test on class 4.A.1 was 8.6. The post test result on class 4.A.1 was higher than 4.A.2 it means that the treatment on experiment class was giving improvement rather than on the control class. This result prove that audio visual media gave improvement on student's vocabulary mastery.

4.10 Evaluation from teacher and student

Table 5. Students Evaluation Result

\begin{tabular}{|l|l|l|l|l|}
\hline No & \multicolumn{1}{|c|}{ Questions } & \multicolumn{3}{c|}{ Central Tendency } \\
\cline { 3 - 5 } & & $\mathrm{N}$ & $\mathrm{M}$ & $\%$ \\
\hline 1 & Does the Stop Motion Video have a good picture & 33 & 3.90 & $78 \%$ \\
\hline 2 & $\begin{array}{l}\text { Does the Stop Motion Video help you to understand English } \\
\text { Vocabulary }\end{array}$ & 33 & 3.81 & $76 \%$ \\
\hline 3 & Is the text on the video clear enough? & 33 & 3.78 & $76 \%$ \\
\hline 4 & Is the audio of the video clear enough & 33 & 3.60 & $72 \%$ \\
\hline 5 & Do you interest to study another material with the video & 33 & 3.66 & $74 \%$ \\
\hline & \multicolumn{1}{|c|}{ Total } & & 18.75 & \\
\hline
\end{tabular}


Table 6. Teacher Evaluation

\begin{tabular}{|c|l|c|c|c|}
\hline \multirow{2}{*}{ No. } & \multicolumn{1}{|c|}{ Questions } & \multicolumn{3}{c|}{ Central Tendency } \\
\cline { 3 - 5 } & & $\mathrm{N}$ & $\mathrm{M}$ & $\%$ \\
\hline 1 & An appropriate illustration with the vocabulary. & 1 & 5 & $100 \%$ \\
\hline 2 & Content and Syllabus matching. & 1 & 5 & $100 \%$ \\
\hline 3 & Animation and audio quality. & 1 & 4 & $80 \%$ \\
\hline 4 & Review section to measure students understanding. & 1 & 5 & $100 \%$ \\
\hline 5 & The general view of Stop Motion video quality. & 1 & 4 & $80 \%$ \\
\hline & Total & & 23 & \\
\hline
\end{tabular}

\subsection{Expert judgment}

\subsubsection{Media}

a. Setting and technique

For the video with daily activity theme, the media expert judgment had categorized it as good.

b. Story development

The timing and story development was good for a short time animation video. The story would be good without too much prologue.

c. Lighting and visual performance

The visual and lighting must be made more bright and colorful because the object was children.

\subsection{Learning style}

Table 7. Learning Style Expert Judgment Result

\begin{tabular}{|c|c|c|c|c|c|}
\hline \multirow[b]{2}{*}{ No. } & \multirow[b]{2}{*}{ Questions } & \multicolumn{4}{|c|}{ Central Tendency } \\
\hline & & $\mathrm{N}$ & $\mathrm{P}$ & M & $\%$ \\
\hline & Visual & & & & \\
\hline & The media already contained an interesting picture and suit & & & & \multirow{4}{*}{$66 \%$} \\
\hline 1 & with the syllabus & 1 & 4 & & \\
\hline 2 & The media used a bright color & 1 & 4 & 3.33 & \\
\hline \multirow[t]{2}{*}{3} & $\begin{array}{l}\text { The media already fill with the activity to help them } \\
\text { studying how to write a good English grammar }\end{array}$ & 1 & 2 & & \\
\hline & Audio & & & & \\
\hline \multirow[t]{2}{*}{4} & The media already have scrutinize activity & 1 & 5 & \multirow{4}{*}{4.00} & \multirow{4}{*}{$80 \%$} \\
\hline & The media already cover an activity for children to & & & & \\
\hline 5 & $\begin{array}{l}\text { communicate with other } \\
\text { The media already covered an activity to help students }\end{array}$ & 1 & 3 & & \\
\hline \multirow[t]{2}{*}{6} & understanding vocabulary correctly & 1 & 4 & & \\
\hline & Kinesthetic & & & & \\
\hline 7 & The Media already content physical activity & 1 & 4 & \multirow[b]{2}{*}{3.33} & \multirow[b]{2}{*}{$66 \%$} \\
\hline 8 & The media give a possibility for students being active & 1 & 2 & & \\
\hline \multirow[t]{3}{*}{9} & \multirow{2}{*}{$\begin{array}{l}\text { The media already helped students to learn vocabulary with } \\
\text { phisical activity }\end{array}$} & & & & \\
\hline & & 1 & 4 & & \\
\hline & Total & & & 10.66 & \\
\hline
\end{tabular}

\section{CONCLUSION}

The media is effective to use in teaching vocabulary to 4 grade SD Muhammadiyah Purwodiningratan 2 Yogyakarta on the academic year 20152016. 


\section{REFERENCES}

Abidin, Mohammad Jafree, Zainol, et all. 2011. Learning Styles and Overall Academic Achievement in a Specific Educational System.International Journal for Humanities and Science. 1 (10). August: 143:152

Asyhar, Rayandra. 2012. Kreatif Mengembangkan Media Pengajaran. Jakarta: Referensi

Brown, H. Douglas. 1987. Principle of Language Learning and Teaching. New York: Longman Pearson

Bussman, Hadumond. 2006. Dictionary of Language and Linguistic. London: Routledge

Farooq, Umar. 2014. Audio Visual Aids in Education, Definition, Types and Objectives. Retrieved on 13 June 2016 from http://www.studylecturenotes.com/curriculum-instructions/audio-visualaids-in-educations-definition-types-and-objectives.

Fernandez, Ibiz.2001. Macromedia flash animation and Cartooning: A Creative Guide. Osborn: McGraw Hill Education

Gogoi, Gunaprova. 2014. Role of Technological Media in English Language Teaching. International Journal of English Language, Literature and Humanity. 2 (7). November: 104-109

Harmer, Jeremy. 2009. How to Teach English. Edinburg: Pearson Longman

Kim, Sung-Nam \& Kim, Soong-Gohn. 2006.A Study on The Essential Element for Animation Using Stop-Motion. International Journal of Multimedia and Ubiquitous Engineering. 1 (2). June : 6-9

Lauder, Allan. 2008. The Status and Function of English in Indonesia: A Review of Key Factor. MAKARA, SOSIAL HUMANIORA. 12 (1). July: 9-20

Nation, Paul.2001. Learning Vocabulary in Another Language. Cambridge: Cambridge University Press.

Nunan, David. 1991. Language Teaching Methodology. A Textbook for Teacher. London : Prentice Hall.

Patel, MF \& Jain, M. Praveen. 2008. English Language Teaching: A Methods, Tool, and Technique. Jaipur: Sun Rise Publisher

Scott, A Wendy \& Ytreberg, H Lisbeth. 1995. Teaching English to Children. London: Longman.

Setyosari, Punaji \& Sulton, H. 2003. Rancangan Sistem Pembelajaran. Malang: Elang Mas.

Sudjana, Nana. 2011. Media Pengajaran. Bandung : Sinar Baru Algesindo

Vocabulary [Def.1]. (n.d.)/ Merriam-Webster online. In Merriam-Webster. Retrieved on February 23, 2016. From http://www.merriamwebster.com/dictionary/citation

Yudi Cahyono, Bambang \& Widiati. 2012. The Teaching of EFL Vocabulary in The Indonesian Context : The state of The Art. UM TEFLIN Journall. 1 (1) January. (n.d) 